\title{
Pavle je Pavel, a ni bil Savel, tudi ni Peter in Pavel ne Peter ali Pavel ne pavliha
}

\author{
Janez Keber (Ljubljana)
}

IZVLEČEK: V̌̌lanku, posvečenem Pavletu Merkuju, avtor obravnava besedje in frazeologijo, povezano z imenom Pavel. V naslovu članka pa bolj retorično odgovorja na vprašanje, ali rek Nomen est omen glede na to ime ter besedje in frazeologijo velja za jubilanta.

ABSTRACT: This article dedicated to Pavle Merkù discusses the vocabulary and phraseology connected with the name Pavel 'Paul'. The article's title provides a more rhetorical answer to the question of whether the saying Nomen est omen also applies to Pavle Merkù with regard to this name, vocabulary, and phraseology.

\section{Uvod}

Z jubilantom Pavletom Merkujem sva se osebno spoznala spomladi 1989, v letu po izidu mojega Leksikona imen. Oglasil se je na Inštitutu za slovenski jezik ZRC SAZU in prinesel s seboj tipkopis prispevka z naslovom Odprto pismo Janezu Kebru. Prispevek, ki je recenzija Leksikona imen, je pod tem naslovom kmalu potem izšel v reviji Primorska srečanja. ${ }^{1}$ To je bila prva ocena Leksikona imen, ki jo je napisal slovenski kolega po stroki ${ }^{2}$, tj. slavist (Pavle Merkù je namreč leta 1960 na Univerzi v Rimu doktoriral iz literarne slovenistike), zato je bila še toliko bolj dragocena. Sledila ji je nadaljnja strokovna diskusija v reviji Mladika. V njej je namreč Merkù od januarja 1988 objavljal svoje prispevke o imenih z naslovom Svetniki v slovenskem imenoslovju. ${ }^{3}$ Začenši z imenom Elisabeth pri črki E je za-

1 Glej Primorska srečanja 1989, št. 95-96, str. 299-301.

2 Po izidu Leksikona imen je sicer izšlo precej različnih domačih in tujih ter večinoma zelo ugodnih ocen in poročil, od slovenskih kolegov slavistov pa razen Merkujeve samo še ocena Janka Modra v Rodni grudi.

3 Kot piše v uvodni besedi v začetku pisanja imenskih člankov v Mladiki in kasneje ponovljeni v knjigi Svetniki v slovenskem imenoslovju je svoje prispevke o imenih začel objavljati zaradi neobstajanja celovitega dela o svetniških imenih v slovenskem imenoslovju: "Ne razpolagamo pa še s temeljito in metodično razpravo o svetniških imenih v slovenskem imenoslovju, s kakršno se že ponašajo drugi evropski narodi. Zato se lotevamo takega poskusa, čeprav se zavedamo, da bo tudi ta študija nujno nepopolna. Sloven- 
ci namreč ne razpolagamo s temeljno zgodovinsko študijo o diahronično in teritorialni razvrstitvi češčenja svetnikov po slovenskem prostoru, ki bi naši študiji morala služiti za osnovo in podporo..."

Glede na povedano je izid mojega Leksikona imen leta 1988 vsekakor zapolnil nekatere vrzeli v slovenskem imenoslovju in razveselil Merkuja, kar je razvidno tudi iz njegovega odprtega pisma. Da je potreba po knjigi o rojstnih imenih v Sloveniji v drugi polovici 80-ih let resnično dozorela, dokazuje razen Merkujevega pisanja Svetnikov tudi dejstvo, da sta knjigi o imenih pripravljala tudi etnolog Damjan Ovsec in Silvester Čuk. Prvi je odstopil od namere, ko je zvedel, da je pri celjski Mohorjevi družbi za tisk pripravljen moj Leksikon imen, ponudbo drugega po objavi pa je ta družba zavrnila in dala prednost moji. Oba sta pred tem imela imenski rubriki v Pionirju in Ognjišču (moje oddaje o imenih so bile v letih 1984-1985 na Radiu Ljubljana). Kasneje je Ovsec izdal samostojni knjižici o Jožefu in Mariji, Čuk pa knjigo Svetniki za vsak dan v dveh delih leta 1999 (I. del januar-junij 1999, II. del julij-december 1999, druga popravljena izdaja leta 2004).

4 Ti prispevki so imeli naslednje naslove: Franc Jakopin, Nekaj pripomb in dopolnil k Merkujevim Svetnikom v slovenskem imenoslovju (str. 151-154; Janez Keber, Ob slovenskem imenoslovju (str. 155-157); Dušan Čop, Pripombe k študiji: Svetniki v slovenskem imenoslovju (str. 158-161). Po izidu knjige smo bili leta 1993 vsi trije povabljeni na tiskovno konferenco v Trst, ki sva se je udeležila Jakopin in jaz.

5 Na kakšen način je Merkù v člankih in knjigi obravnaval imena, je zapisano v že omenjeni uvodni besedi: "Izhajali bomo iz svetniških imen, iz katerih so nastala slovenska krajevna in osebna imena, v latinski obliki, kakršno uporablja rimska Cerkev, in jih bomo nanizali v alfabetskem redu. Sledila bo, kjer je mogoče, razlaga samega imena s seznamom svetnikov istega imena, ki jih Cerkev časti.

Iskali bomo zgodovinske vire iz poznega srednjega veka, v katerih so prvič izpričane slovenske imenske oblike, kakor so se razvile iz latinščine naravnost ali po posredovanju sosednjih narodov: utemeljiti bomo skušali zgodnjo prisotnost teh imen pretežno na slovenskem Zahodu tudi iz virov, ki niso še objavljeni in javnosti dostopni.

Skušali bomo slediti razvoju imenskih oblik v slovenskem prostoru skozi stoletja do današnje rabe in navajali, kolikor so nam dostopne, oblike osebnih imen, iz njih nastalih priimkov, vzdevkov, hišnih imen, imen naselij in zaselkov, ledin, voda in gora..." 
spoštovanega ruskega kolega Valerija M. Mokienka ${ }^{6} \mathrm{v}$ čast jubilanta odločil za zapis o imenu Pavel ter besedju in frazeologiji, ki sta povezana s tem imenom.?

V nadaljevanju prehajam na obravnavo imena Pavel ter besedja in frazeologije, ki izhajata iz njega.

\section{Pavel - Pavle, Pavliha}

Ime Pavel je med najpogostejšimi moškimi imeni na 81. mestu. Tako je bilo leta 2006 v Sloveniji po podatkih Statističnega urada RS z imenom Pavel poimenovanih 2926 (1971: 4730; 1994: 3671) oseb. Pogostejša je bila ženska oblika Pavla (4234, 64. mesto) manj pogosta Pavlina (786, 209. mesto). Pavle (251, 353. mesto) je manjšalna in (ali) ljubkovalna različica imena Pavel. Zaradi pogoste rabe (prim. Anže, Brane, Jože, Tine, Tone) se manjšalni in ljubkovalni pomen imen na - $e$ večinoma že izgublja. Tako tudi pri imenu Pavle. ${ }^{8} \mathrm{~V}$ taki funkciji bi zdaj uporabili obliko Pavelček.

Ime Pavel izhaja iz latinskega imena Paulus. Razlagajo ga iz latinskega pridevnika paulus ‘majhen'. Pavlu je protipomensko ime Maksim, latinsko Maximus z nekdanjim pomenom 'največji'. Zgodovinske osebe so ob svojem imenu pogosto imele vzdevek Veliki, npr. Aleksander, Karel, Peter Veliki, zelo poredko Mali, npr. Pipin Mali.

V nasprotju z obliko Pavle je večalna (lahko tudi slabšalna) oblika imena Pavel ime Pavliha. ${ }^{9}$ To danes ni več v rabi, da pa je obstajalo, dokazuje današnji priimek Pavliha ${ }^{10}$ (2006: 92 oseb) in nekdanja raba, npr.: Nekdaj v poznej noči je lezel

6 Valerij M. Mokienko je namreč v čast 70-letnice znanega beloruskega jezikoslovca Adama Supruna napisal članek o imenu Adam v slovanskih jezikih. Moj pristop ne bo toliko primerjalno slovanski, vsekakor pa bom upošteval vsaj srednjeevropski jezikovni bazen, in to ne samo z imenoslovnega, ampak tudi z leksikološkega in frazeološkega vidika.

7 Svoj priimek je poskusil razložiti že sam jubilant. Razlaga priimka Merku je npr. v njegovi knjigi z naslovom 1300 primorskih priimkov (str. 65-67). Ta izhaja iz kraja Velike Žablje v ajdovski občini na Vipavskem iz hiše, ki se ji pravi po domače pri Polákcih, kjer se je sredi 19. stoletja rodil njegov ded Josip Merku. Priimka Merkù v Sloveniji ni več, obstaja pa njegova izvorna različica Merkelj (po podatkih Statističnega urada RS leta 2006: 25 oseb).

8 Da je oblika Pavle trdno zasidrana tudi v ljudskem jeziku, dokazuje njena prisotnost v slovenski ljudski pesmi, npr.v razdelku Posmehulje osebam po imenih:

7673. (Kranjska) Dandanašnji mladi Paglavci zabavljivo omenjajo žab, ko si nagajajo: Pavle Paližgal /Žabam je žvižgal, /Žabe lovil, / pa nobene dobil! (SNP IV 375).

9 O večalnih oblikah - Vergrößerungsformen - z priponskima obraziloma -iha, -uha govori že F. S. Metelko v svoji slovenski slovnici Lehrgebäude der Slowenischen Sprache, 1825, str. 63, in navaja besedi pavliha, pavluha ein Harlekin. Prav tam omenja še priponsko obrazilo - uša z zgledom Maruša groß und verächtlich (Marie).

${ }^{10}$ Priponsko obrazilo -iha je v priimkih zelo redko. Tako je npr. še v priimkih Jeriha, Lavriha, Lovriha, Urbiha, Ladiha, Rumiha ter Stariha, Dobriha. Tvorbeno in pomensko so priimkom na -iha blizu priimki na -iša, npr. Jakiša, Braniša, Staniša, Deniša, Mikiša, Jeriša, Periša, Jutriša, Lavriša, Mikiša itd., dalje -uha, npr. Raduha, in -uša, 
$-\quad$ Šarevčev Pavliha domu (I. Tavčar, Miha Kovarjev, Slov. knj. 1880, 56). Neko nedeljo napil se je v gostilni, pretepel Polončevega Matijčka, opraskal lica Kovačevemu Pavlihi ... (I. Tavčar, Med gorami, LZ 1882, 168). Slabšalni pomen imenske oblike Pavliha se je v procesu leksikalizacije uveljavil v poimenovanju komične figure in poimenovanju za 'šaljiv, hudomušen človek': pavliha (v pomenu 'šaljiva, burkasta figura’ pisano tudi Pavliha), o čemer pa glej v nadaljevanju.

Iz imena Pavel in njegovih različic so nastali številni priimki. Po priiimkovnem procesu pa sta priimka postala tudi Pavel (2006: 77 oseb) in Pavle (7).

Pavel je tudi zelo znano svetopisemsko ime. Pavel iz Tarza, pred spreobrnjenjem Savel, je zgodovinska oseba iz 1. stoletja. Najprej je bil preganjalec kristjanov, leta 34 pa se je spreobrnil v Jezusovega učenca. Bil je na misijonskih potovanjih na Cipru, v Mali Aziji, Makedoniji, Grčiji in ustanavljal cerkvene občine. V Rimu so ga obglavili leta 67. V Pavlovih pismih, ki so del nove zaveze, so opisani Kristusovo poslanstvo, njegova smrt in poveličanje. Pavel naj bi mlado krščanstvo prilagodil izraznim oblikam orientalsko-helenističnega kulturnega sveta in mu utrl pot do statusa svetovne religije. Praznih apostolov Petra in Pavla je 29. junija, spreobrnitev apostola Pavla pa je v koledarju 25. januarja.

Kot vsa znana imena se tudi Pavel kot tudi Peter pojavljata kot sestavini frazemov, v procesu leksikalizacije pa so iz njih nastali najrazličnejši izrazi. Dlje časa je neko ime v nekem prostoru, dlje živi med ljudmi, več možnosti je, da jih najdemo v znanih frazemih in t. i. izimenskih izrazih. V zvezi z imenom Pavel bom v nadaljevanju svojega prispevka pojasnil izvor frazemov iz Savla postati Pavel, Peter in Pavel, Peter ali Pavel, nadalje izraz pavliha (Pavliha) in z njim povezane frazeme in izraze.

\section{3 iz Savla postati Pavel}

S svetopisemskim Pavlom je povezan knjižni frazem iz Savla postati Pavel v pomenu 'iz človeka s slabim, negativnim značajem postati človek z dobrim, pozitivnim značajem; zelo se spremeniti; preporoditi se', npr.: Če nisem bil do sedaj Slovan, ne bodem nikedar. Da bi postal Pavelj iz Savla, tega čuda se mi ni več nadejati z nebes; ne prikliče ga ne molitev, ne pokora! (J. Stritar, Pogovori, Zvon 1879, 46). Iz Saula je postal Pavel, srečanje z otroškim vrtcem na ljubljanski cesti je njegova pot v Damask, otroci so mu prišli v srce kot Kristus s hostijo pri prvem obhajilu (T. Kermauner, Na poti k niču, 1968, 23). To izpričujejo napr. nravstveno “izpreobrnitev", ko recimo kdo iz Savla postane Pavel (K. Ozvald, Osnove psihologije, 208).

Meni se ni zbudilo rodoljubje o tej in tej priložnosti, kakor se je temu ali onemu pri nas, ki ga je neka čudovita prikazen hipoma izpremenila iz Savla v Pavla (J. Stritar, Lit. pog., Z. 1876, 29). Spreobrnila me je iz Savla v Pavla švedska pisateljica Selma Lagerlöf (Burnett-Pribil, Mali lord I).

npr. Pauluša, Pavluša, Ivanuša, Maruša, Petruša ter Bratuša, Vratuša. Da je ob priimkih Pavliha, Pauluša in Pavluša obstajal tudi priimek ali ime Pavliša, kaže priimek 
Napis Made in Germany so leta 1887 uzakonili Britanci, da bi domače proizvode dovolj jasno ločili od tistih s celinske tekmice in tako otežili prodajo nemških proizvodov... Najkasneje po drugi svetovni vojni se je slabševalna označba spremenila v znamenje kakovosti in izdelki Made in Germany so zasloveli po vsem svetu. "Znamka je iz Savla postala Pavel," komentira Doris Möller, ki je prepričana, da pobuda med članicami EU ne bo dobila podpore (Delo, 31. jan. 2004, Nova beseda $=$ NB).

Možnost, da bi Haider nekoč postal pravi avstrijski zvezni kancler, ne le kancler v senci, kar je zdaj, je bila po vsej verjetnosti dovolj zastrašujoča, da so se države EU odločile za ukrepe zgodnjega omejevanja škode. V zakup so vzele očitek, da avstrijski vladi niso hotele dati priložnosti in da Haiderjeve spremembe iz Savla v Pavla niso nagradile s potrpežljivim in vzgojnim zaupanjem (Delo, 12. feb. 2000, NB). Dosti je bilo takšnih preobrazb iz Savlov v Pavle, ne le v takratnih razmerah, ampak vselej na velikih prelomnicah; zato ta epizoda v ničemer ne jemlje časti predavatelju, ki je kmalu zatem sprevidel svojo napako, se vključil kot prediren znanstvenik v slovensko kulturno snovanje, prešel v času odločitve k Slovenskemu društvu... (M. Mušič, Novomeška pomlad, 1974, 71).

Svetopisemski Pavel iz Tarza je bil pred spreobrnitvijo Savel in vnet preganjalec kristjanov. V Jezusovega učenca se je spreobrnil na poti v Damask leta 34, ko je sprejel tudi novo ime. Frazem se izvorno nanaša prav na to spreobrnitev, se pa, kot kažejo navedeni zgledi, lahko nanaša tudi na stvari. Slovenskemu iz Savla postati Pavel, ki ima tudi različice spremeniti (se) iz Savla v Pavla, sprememba iz Savla v Pavla ipd. (gl. navedeno gradivo) ustrezajo nemško aus einem Saulus wurde ein Paulus in sopomenski seinen Tag von Damaskus erleben ter hrvaško ali srbsko od Savla postao je Pavle. Nemški frazem seinen Tag von Damaskus erleben prav tako temelji na Savlovi spreobrnitvi na poti v Damask. V zgoraj navedenem gradivu ga najdemo tudi pri Kermaunerju: srečanje z otroškim vrtcem na ljubljanski cesti je njegova pot $v$ Damask. Sicer pa so frazem iz Savla postati Pavel z različicami poznali že naši klasiki (gl. pri J. pri Stritarju), o spreobrnitvi pa govori tudi že ljudska pesem:

\section{Pavelj apostelj}

O sveti Pavel, si poprejšnji Savel, / sam Bog pozneje te prestavil... (SNP III, 842, XIV, 2).

\section{Peter in Pavel}

Po apostolih Petru in Pavlu je nastal frazem Peter in Pavel v pomenu 'vsakdo, kdorkoli', a je raba v tem pomenu bolj redka kot raba sopomenskega Peter ali Pavel, npr. Moj bog, zdi se mi, da ni nič in nikogar na svetu, za kar in kogar bi naša Barica ne spraševala. Peter in Pavel, njej je vseeno, ona sprašuje, sprašuje in ti moraš odgovarjati (Zofka Kvedrova, Veliki in mali ljudje, NB).

Frazem Peter in Pavel se lahko uporablja tudi zanikano, npr. Ne bom potreboval ne Petra ne Pavla, tj. 'nikogar'. Ustrezajo mu hrvaško ali srbsko Petar i Pavao, Petar i Pavle v pomenu 'vsakdo', v francoščini Paul et Pierre, Paul et Jacques 
$\hookrightarrow \quad$ v enakem pomenu. V zvezi s tem omenjam še francosko découvrir saint Pierre pour couvrir saint Paul, angleško to rob Peter to pay Paul v pomenu 'vzeti enemu, da bi dali drugemu'. Omenjenim parom bi lahko dodali še poljski rimani par Pawel-Gawel. To sta junaka pesmi Aleksandra Fredre iz komedije Pan Jowialski.

Peter in Pavel pomeni tudi 'šaljivo tekmovanje' (gl. R. Gööck-S. Krušnik, Štiristo najlepših, 1967, 202). V literaturi je imenski par Peter in Pavel posrečeno uporabil Janez Trdina: Kakor je nekdaj Peter, rekel je tudi Pavel, naj ga svobodno obleče (Peter in Pavel, LZ 1884, 660).

Kot dvojčka pa nastopata Peter in Pavel v naslednjem navedku: Ljubljana - Štiriintridesetletna brata Peter in Pavel K., doma sta iz iz Bele Krajine, se bosta morala zagovarjati pred sodniki zaradi kaznivega dejanja goljufije, ker naj bi se bila pri uvozu sladkorja v celoti izognila plačilu vseh dajatev in tako državo oškodovala za enajst milijonov 134.932 tolarjev (Delo, 6. avg. 1999, NB).

Nastanek dvojčičnega izraza Peter in Pavel, kot tudi Peter ali Pavel temelji na skupnem delovanju Petra in Pavla kot prvih krščanskih apostolov. O tem skupnem delovanju govorijo še naslednji navedki:

Vodilni strokovnjak za Novo zavezo Ben Witherington III. pa razkriva presenetljiva dejstva o zgodbi, za katero smo vsi mislili, da jo poznamo: o Jezusovi vzgoji v veliki, versko konservativni judovski družini, o nezaupanju njegovih bratov in sestra do njegovih naukov vse do Jezusove smrti, o tem, kako je Jezusov brat Jakob postal voditelj judovskega krščanskega gibanja v Jeruzalemu, pri katerem sta nasvet in privoljenje iskala tudi Peter in Pavel, o Jakobovi vlogi v velikem cerkvenem sporu v prvem stoletju in o tem, kako je napisal eno od svetopisemskih knjig, o njegovi mučeniški smrti in kako ga je iz zgodovine izbrisala Rimskokatoliška cerkev (Delo, 3. dec. 2003, NB). Jakob je dolgo deloval v senci teh velikanov. Vendar sta Peter in Pavel, kot je razvidno iz Gal 1-2 in Apd 15, odgovarjala Jakobu in se podrejala njegovim zapovedim. Potrditev za to najdemo v opisu znamenitega zbora v Apd 15. Tam sta govorila Peter in Pavel, končno odločitev pa je sprejel Jakob (Delo, 3. jan. 2004, NB). Katoliška cerkev je godova obeh apostolov združila na isti dan. Peter in Pavel sicer nista umrla istega dne, niti v istem letu, toda njuni življenjski zgodbi se tesno prepletata. Po drugem izročilu pa je njun god 29. junija zato, ker naj bi bili 29. junija 258 izkopali kosti Petra in Pavla iz grobov zaradi nevarnosti, da bi jih oskrunili (Delo, 29. jun. 1999, NB).

\section{Peter ali Pavel}

Po apostolih Petru in Pavlu je nastal tudi frazem Peter ali Pavel v pomenu 'kdorkoli', npr.: Za tatu je predobro oblečen. Pa naj bo Peter ali Pavel, denar ima, kakor vse kaže, in treba mu bo pač dati, kar bo zahteval. Saj ne ločimo med poštenim in nepoštenim denarjem (Ciril Kosmač, Prazna ptičnica, NB). "Kaj nam hoče, ako ga ne dobomo!" reče drugi. "Glave si ne bom lučal po kamenju za njim, naj mi zapoveduje Peter ali Pavel." "Ti lahko govoriš," reče župan, "a krop bo mene najbolj poparil (J. Jurčič, Domen, NB). Zapomnite si to! Peter ali Pavel: godlja je godlja! $\mathrm{Na}$ vaši posetnici, pribiti tam zunaj, sem bral, da ste ta in ta; modroslovec (Rado 
Murnik, Nirvana, NB). Kako neki! Ime je postranska reč; naj bi bil napisal to brošuro Peter ali Pavel, stavim, da bi se ne bil domislil ne Petkovška, ne Groharja, ne Jakopiča... (Ivan Cankar, Pozabljene rokavice, Kritike, NB). Tragikomično pa je to, da se država v človekovo poslednjo voljo vmešava čisto po nepotrebnem, saj od tovrstnega vmešavanja nima nobenih materialnih koristi niti takega vmešavanja ne narekujejo višji državni interesi. Državi je popolnoma vseeno, ali neko premoženje podeduje Peter ali Pavel (Delo, 9. jun. 2001, NB).

Leksikalizacija najbolj znanih imen ali njihovih različic v izimenske izraze, ki označujejo splošne, pogosto tudi komične ali negativne človeške like, je splošno znan pojav (npr. pri imenih Janez, Jaka, Jurij, Pavliha; podrobneje o tem glej v navedeni literaturi). Redkejši so pri imenih v paru, kot Peter in Pavel ter Peter ali Pavel. V slovenskem jeziku bi bil ustrezni par še Ciril in Metod, kot moško-ženski par pa Janez in Micka, ki sta že v ljudski pesmi. V evropskem imenoslovju je takih parov še več, uporabljajo pa se zlasti pri poimenovanju dvojčkov. ${ }^{11}$

\section{6 pavliha (Pavliha)}

\section{1 pavliha (Pavliha) 'šaljiva, burkasta figura v gledališču'}

Igral je harmoniko, gosli, klarinet, citre in trobento, sploh vse, kar mu je prišlo v roke, pel pa je tako lepo, da je ženske spreletavala mrščavica. Bil je potepuh in nekakšen Pavliha. Uganjal je prijetne, včasih pa tudi malce neprijetne norčije (C. Kosmač, Tantadruj, NB). "Kajpak, kajpak! - Povedaj mi ti rajši, ko se že tako lepo poznava od nekdaj, s kom si se doma razprl ali stepel, da se zdaj že tri dni tako tiho in na pol skrivaje poteplješ tod okoli ter si kakor Pavliha, ko je mislil, da ga je medved snel?" (J. Jurčič, Sosedov sin, NB). Ta je zapeljal že dosti žensk. Laže kot Pavliha. Iz bataljona te ne dam; čeprav pride tisti iz divizije, ki rad kriči." (Matevž Hace, Naši obrazi, NB). Vsa ta modrovanja imajo telesne in duševne oči zamegljene! Poznam nekaj Hamletov, ki so klavrni Pavlihe. Poznam Pavliho, ki je žlahten Hamlet (Delo, 29. jan. 2000, NB).

Književnik in poslanec Tone Partljič je kabaret napisal na pobudo gledališča, s katerim je v preteklosti sodeloval tudi že kot njegov umetniški vodja. Kljub slabim izkušnjam s tem posebnim odrskim žanrom se je odločil, da bo vpletel v anekdotično kabaretno obliko nekatere svoje humoreske o politiki in jih povezal med seboj v celoto s tradicionalnim likom Pavlihe kot ljudsko pojavnostjo pomembne, a najpogosteje skrbno skrite psihološke razsežnosti slovenskega človeka (Delo, 22. apr. 1998, NB). Za režiserja Andreja Stojana je najdragocenejša avtorjeva misel o neumrljivosti Pavlihe (in pavlihovstva). Sicer je v samem zaključku kabareta videti, da ga je nazadnje pokopala prav prva demokratična slovenska država, toda prav $\mathrm{z}$ avtorjem, vztrajnim komediografom, živi Pavlihovo osvobajajoče izročilo še naprej (Delo, 22. apr. 1990, NB).

Ker pa po smerti slavnih mož Kljukca in Pavlihata nihče še v križem svet ni

${ }^{11}$ V zvezi s tem je vredno omeniti monografijo Milice Lađević z naslovom Tvorbeni modeli imena blizanaca u Vojvodini (Novi Sad 1988). 
$\hookrightarrow \quad$ poti najdel, nam ostanejo ti imenitni in visoko učeni spisi zgubljeni (J. Trdina, Pripovedka od zlate hruške, LČ 1850, 284). Kmetje imajo še celó veselje nad lažnjivim Klukcem (Münchhausen) in nemškim Pavlihom v slovenski obleki (Eulenspiegel) (F. Levstik, Popotovanje, SG 1858, 82).

Njihov Pavliha je Švanda dudák, po katerem se je imenoval tudi nekdanji humoristični list. Iz davne češke preteklosti je ohranjen spomin na dvornega norca kralja Jiřija Poděbradskega Palečka; tudi po tem se je imenoval neki češki humoristični list (Slavko Krušnik, Smeh stoletij, NB).

Pavliha, pavliha je glavni junak pri klasičnih igrah za ročne lutke, slovenska inačica za nemškega Gašperčka (Kasper). V naše lutkarstvo ga je leta 1939 uvedel dr. Niko Kuret. ${ }^{12}$ Po leksikalizaciji sta se iz tega poimenovanja razvila pomena 1. šaljiva, hudomušna figura v lutkovnem gledališču 2. ekspr. šaljiv, hudomušen človek. ${ }^{13} \mathrm{~V}$ Pleteršnikovem slovarju najdemo tudi sopomenke pavlišec, pavlišek, pavluha. Zadnja je tudi v reklu Pavluha nima sluha, dokler mu hrbta ne nabuha v pomenu 'kdor noče slišati, bo pa čutil'. Kot je razvidno iz zadnjega zgleda, v češčini našemu Pavlihi ustreza Švanda dudák. Blizu temu je tudi hrvaško kajkavsko dudek. V italijanščini izraz paolino nuovo pomeni 'tepec', izraz paolotto pa 'menih pavlanec' in 'klerikalec, pobožnjakar', v angleščini Paul Pry 'radovednež'. Sicer pa našemu pavlihi v angleščini ustreza Merry-Andrew 'pavliha, šaljivec'; nekdaj 'pomočnik sejmarskega mazača', v poljščini pa polyszynel 'pavliha, burkež; javna skrivnost'. Slednji izhaja prek francoskega policinelle iz italijanske ženske komične figure Pulcinella. Ta je tudi v izrazu il segreto di Pulcinella v pomenu 'kar vsi vedo'.

Slovenski Pavliha je tudi v pregovoru Pavliha ljudi gliha. Ruska različica tega pregovora se glasi U vsjakogo Pavla svoja pravda.

\section{2 pavliha 'šaljiv, hudomušen človek'}

Naj vam povem, da je Washington kalvarija za snoba, za vsakogar, ki je kaj vreden, ker se mora tukaj spoprijemati z vsemi temi pavlihi in padarji, ki so preslepili ljudi, da so volili zanje... »Vsi niso pavlihe.« (G. Vidal-J. Fistrovič, Washington, D. C., 1976, 77). Najprej mora priti kdo - kdo, ki vas bo spet spravil v smeh, dober, vesel pavliha, plesalec in vetrnjak in divjak, kakšen star norec: - kaj se vam zdi? (F. Nietzsche-J. Moder, Tako je dejal Zaratustra, 1974, 284). Eden je bil visok, suhljat, s petelinjim obrazom, drug pa bolj majhen, debelušen, z obrazom pavlihe (B. Zupančič, Plat zvona, 1970, 144). Videl se je kot nebogljenega tujca, zabavnega malega pavliho, ki ga ta velikanska in daljna bitja ljubkujejo in negujejo (Thomas Wolfe-M. Mihelič, Ozri se proti domu, angel, 1957, 47). Ubogi pavlihe, vi, politiki,

${ }^{12}$ V zvezi z njegovo dejavnostjo je tudi t. i. Pavlihova druščina - lutkovna skupina, ki je pod vodstvom dr. N. Kureta 1. 1939 in 1940 redno mesečno nastopala v Ljubljanskem radiu.

${ }^{13} \mathrm{Na}$ teh pomenih temelji tudi poimenovanje Pavliha za satirični list, katerega tri številke je na Dunaju uredil Fran Levstik. Kot humoristični list je Pavliha izhajal še v letih 1892-1894, leta 1909 Nemški Pavliha v slovenski obleki (v Ljubljani, J. Giontini), po letu 1944-1999 pa s presledki njegov naslednik tednik Pavliha, zabavno-satirični list za resno zafrkancijo. 
muči vas častihlepje, ko mislite, da ste voz zgodovine, a vas dogodki dneva podijo pred seboj kot pleve. Noben strankarski človek ne razume niti zvestobe samemu sebi (Delo, 2. dec. 2004, NB).

\subsection{1 imeti koga za pavliho 'norčevati se iz koga'}

Zame bi bilo važno, sicer se bom imel vedno le za pavliho (V. Ocvirk, Hajka, 1957, 133).

6.2.2 biti komu za pavliho 'pustiti, da se kdo norčuje iz koga'

Glej, da spodobno prišantaš do jame/ in z vso častitljivostjo ležeš v grob,/ če ne, boš še po smrti nam pavliha (O. Župančič, Veronika Deseniška, 1924, 14, in Dela 3, 1936, 39).

Lahko sem pač podložnik, celo suženj, toda za pavliho nočem biti niti Gospodu Bogu (M. Klopčič, Demon, 259).

6.2.3 biti pavliha, postati pavliha 'biti, postati smešen, hudomušen človek'

Zapisi, da je prepovedal balet, porušil gledališča in pozaprl bolnišnice zunaj glavnega mesta, so iztrgani iz konteksta in nimajo zveze s tukajšnjo resničnostjo," je poudaril sogovornik in opozoril, da Turkmenbaši le ni bil tak pavliha, kot so ga skušale orisati tuje tiskovne agencije, ki so včasih kar tekmovale, katera bo zapisala najbizarnejšo vest o njem. Mož pa je imel izredno moč in so bile njegove odločitve vse prej kot smešne za tamkajšnje prebivalce (Delo, 27. dec 2006, NB). Mislil sem že res, da si Pavliha, / A ostal si, sósed, mož-beseda! / Čarodéj si; rad ti čast priznávam (A. Aškerc, Balade in romance, NB). Razlika je le ta, da os tedaj to sublimacijo tudi izvedli, Husserl pa samo govori o njej. Danes je pač težko spustiti se v tako početje, ne da bi postal smešen Pavliha (C. Logar, Femenologija, 1971, 583).

6.2.4 igrati pavliha 'igrati šaljivo, burkasto figuro'

Preden je /Chaplin/ podpisal pogodbo s podjetjem Keystone, kjer naj bi igral pavlihe, je bajal o vlogah ljubimcev, sanjaril, da bo igral Romea (G. Sadoul-F. Brenk, Zgodovina filma, 1960, 152). Funkcionarji se od svojih odlično plačanih služb prostovoljno zagotovo ne bodo poslovili, prav tako se bo, žal, vedno našlo dovolj študentov, ki bodo za majhne privilegije, kakor so sejnine in brezplačna pijača v študentskem klubu Štuk, pripravljeni igrati pavlihe v tako imenovanem parlamentu (Delo, 17. nov. 2001, NB).

Izraz pavlíha (1. šaljiva, hudomušna figura v lutkovnem gledališču 2. ekspr. šaljiv, hudomušen človek) se je izkazal tudi kot izredno produktivna podstava za izraze - tvorjenke, ki se pomensko navezujejo nanjo. To so: pavliharija, pavliharski, pavliharstvo, pavlihast, pavlihiada, pavlihovanje, pavlihovati, pavlihovski, pavlihovski sam., pavlihovsko prisl., pavlihovstvo (glej ponazoritve v nadaljevanju).

pavliharija 'šaljivo, burkasto obnašanje, dejanje'

Pridušeno so oporekali starejši gorečneži in poznavatelji. Opičarije! Pavliharije, ki bi jih v prejšnjih časih ne bili trpeli!... Na glas pa si niso upali ziniti nobene, ker jih je sililo k molku ljudsko kričanje in navdušeno vzklikanje (V. B. Ibanez-S. Leben, Krvave arene, 1932, 50).

pavliharski ‘tak kot pri pavlihi; šaljiv, hudomušen'

Edino, kar je, je dejstvo, da tisti, ki v nekem okolju nastopi z brezzvezno pesniško govorico, požanje efekt nekakšne osuplosti - pa še ta »inovator« postane hi- 
$4 \quad$ tro celo za naklonjene opazovalce neprostovoljno smešna prikazen, medtem ko je množici sploh samo dobrodošel povod za pavliharsko oponašanje, ki v tem primeru vsebuje precej resnice (M. Kramberger, Pazljivejša branja, 1975, 341). šnosti'

pavliharstvo 'vse, kar nosi znake Pavlihe = norca, torej višek norosti in sme-

Mislim, da uvidite, koliko mi dolguje ta čudna družba, ko skuša s svojim pavliharstvom izvajati med ljudmi neko tiranijo... (Erazem Rotterdamski-Sovre, Hvalnica norosti, 83).

pavlíhast 'tak kot pri pavlihi; šaljiv, hudomušen, burkast'

pavlihasti Kotzebue (A. Funtek, LZ 20, 34) burkast, šaljiv. »Bolje zame, če bi bil tak kakor ta ubogi Peggotty ali njegov pavlihasti nečak«, je rekel... »kot pa jaz, ki sem desetkrat bogatejši in desetkrat umnejši, pa se moram mučiti sam s seboj (Ch. Dickens-O. Župančič, David Copperfield II, 1937, 36). - Ali bi tole rad videl, kljukec pavlihasti? - je zaklicala, se čudovito gibčno vzravnala in se spet obrnila proti Fominu (Šolohov, Tihi Don IV, 412). Nedavno mi je sin prinesel iz šole oceno za vedenje »prav dobro...« Pa sem šla v šolo in povprašala učiteljico, kaj je bilo. Povedala mi je dobesedno takole; »Veste, tako je pavlihast, da mi spravi v smeh ves razred (Pavliha, 1965, št. 9, 2).

pavlihiada 'naziv za smešno lutkovno igro, v kateri leži vsa teža igre na $\mathrm{Pa}-$ vlihi'

Po njegovem mnenju /mnenju St. Lebna/ je bil namreč »Cervantes v svoji preprosti, tako pristni, prostodušni in že ljubeznivi naivnosti ... trdno prepričan, da se mu je z Don Kihotom posrečila imenitna knjiga za zabavo in kratkočasenje, imenitna pavlihiada« in prav zaradi tega vse do svojega zadnjega diha ni niti od daleč samo slutil, kaj je napisal«,... (D. Pirjevec, Evropski roman, 1979, 443).

pavlihovanje 'posnemanje, igranje pavlihe'

... ker je igral Foma Fomič še za svojega pavlihovanja na damski polovici generalove hiše povsem drugačno vlogo (Dostojevski-V. Levstik, Selo Stepančikovo, 9).

pavlihovati 'biti, obnašati se kot pavliha' 16).

On je pavlihoval - zdaj je čutil potrebo, da bi imel sam svoje pavlihe (idem,

pavlihovski 'nanašajoč se na pavlihe'

Po Inemannovem odhodu, ko je vse bolj prevladoval Govekarjev vpliv, so Verovška radi uporabljali za pavlihovske vloge (D. Moravec, Slovensko gledališče Cankarjeve dobe (1892-1918), 1974, 96). Ne glede na to, da so tako aktivisti Jurijevega ali mežnarji Nepomukovega ter celo komolčarji Boltežarjevega kova že oveneli tipi včerajšnjega dne, ne presegajo niti humor in posmeh, niti drastična pretiranost, niti pavlihovske domislice ravni enodnevne anekdotike in tudi do resnične, pristne komedijske sproščenosti ne zavro (V. Predan, Sinočnje premiere, 1974, 158). Prvi predlaga ta sestanek stari Karamazov, in sicer v šali. Ta predlog je ena izmed njegovih pavlihovskih gest in zvijačnosti, kakor pravi Dostojevski (Josip Vidmar, Meditacije, 1934, 175).

Ti glumači so po sejmih in na proščenjih zabavali preprosto ljudstvo s svojimi 
pavlihovskimi tipi (Arlecchino, Pulcinella, Pantalone, Brighella; Dottore, Capitano, Colombina itd.) (F. Bohanec, Estetska vzgoja, 1967, 61/62).

pavlihovski sam.

Nekaj pavlihovskega se je prebujalo v njem. Imelo ga je, da bi se na glas zasmejal, ali pa mahnil s stisnjenimi pestmi po vratih (I. Koprivec, Hiša pod vrhom, 1957, 441). Držal se je resno in strogo, dasi je razdiral take pavlihaste (R. Murnik, Na Bledu, 144).

pavlihovsko prisl. 'kot pavliha, burkasto, smešno, hudomušno'

Pieta je zamikalo, da bi se pavlihovsko obnašal - nadvse rad bi se napravil nevidnega, skrit za tradicionalno masko klovna (J. Updike-M. Mihelič, Zakonski pari, 1971, 412). Toda na ta predlog je nesrečnež izbočil obrvi, večkrat odkimal s svojo kot gobs golo glavo, da bi pokazal svoj odpor, češ: »Ne, ne, ne Lyskamm - Zermatt, Zermatt!«. Stisnil je pest in jo potisnil med svoje pavlihovsko nabrane obrvi (J. Kugy-M. Lipovšek, Božanski nasmeh Monte Rose, 1976, 68). Med svojimi vrstniki ni bil priljubljen. Da bi se jim nekako prikupil, je počenjal vse mogoče neumnosti in nerednosti: obnašal se je pavlihovsko (Vojan Arhar, Otrok in družina, 1962, 48)

pavlihovstvo ekspr. 'lastnost šaljivega, hudomušnega človeka' in ‘šaljivo, hudomušno dejanje'

Skoraj nemogoče je ilustrirati miselno in kritično bogastvo s posameznimi primeri, saj se v florentinskih nočeh preliva domislica v filozofsko oceno, kritična sodba v literarno impresijo. Neredko so nasprotniki skušali potopiti Heineja zaradi njegove polemične ostrine v pavlihovstvo (B. Štih, Tema in antitema, 1982, 130). Verjamem v razumnega, čustveno bogatega, videnjskega in osebnostno polnokrvnega ustvarjavca, vse drugo je za moj okus spretnjaštvo, rokodelstvo, pavlihovstvo, ki nima nikakršne zveze s poslanstvom in cilji umetniškega gledališča (M. Mahnič, Upanje, 1971, 19). »Pravica pesti« je tipičen Kirstov roman skrajnje napetosti. Priljubljeni avtor pripoveduje zgodbo, polno presenečenj, na neposredni in odkritosrčni način, prepleten s suhimi, udarnimi pavlihovstvi, kakor tega nihče drug ne zna (Delo, 13. 11. 1970, 12).

Z izrazi, izpeljanimi iz izvirno slovenskega poimenovanja komičnega lika pavliha, končujem prispevek o imenu Pavel ter besedju in frazeologiji, povezanim z njim. Iz zapisanega je glede na v naslovu retorično podane trditve, ki temeljijo na reku Nomen est omen (Ime je pomenljivo), možno ugotavljati, ali in v kolikšni meri se le-te lahko nanašajo na ime jubilanta Pavleta Merkuja. Vsekakor je ta Pavle poseben Pavel, ki že z obliko in pomenom svojega imena prerašča izvorno »majhnost« Pavla v njegovo nasprotje. Pri tem pa prevzema veliko svetopisemske simbolike in apostolstva Pavla, saj je naš jubilant izreden ambasador slovenstva v zamejstvu in tujini sploh ter je lahko svetel zgled tudi vsem v matični domovini. Z zanikanimi oblikami frazemov in izimenskih izrazov, izhajajočih iz imena Pavel (ni Peter in Pavel ne Peter ali Pavel $=$ ne kdorkoli, ne pavliha) se pomembnost jubilantovega dela in njegove izredne osebnosti še poudarja. Vsaj zame pa o odprtosti njegovega 
značaja in raziskovalne nesebičnosti še vedno najlepše govori njegovo Odprto pismo Janezu Kebru, ob katerem sva se osebno spoznala.

\section{Viri in literatura}

Byryh, A.K., Mokienko, V.M., Stepanova, L.I., Slovar' russkoj frazeologii, Istoriko-etimologičeskij spravočnik, Sankt-Peterburg 1988.

Gak, V. G. \& al., Francuzsko-russkij frazeologičeskij slovar, 804.

Keber, Janez, Nekateri semantični vidiki in motivi prehoda osebnih imen v občna imena v slovenščini, Traditiones 23 (1994), Ljubljana, 27-32.

Keber, Janez, Osebna imena v ljudskih pesmih, Traditiones 28 (1999), 1, Ljubljana, 269-280.

Keber, Janez, O strukturi rojstnih imen v Sloveniji, Jezikoslovni zapiski 7 (2001), št. 1-2, 21-111.

Keber, Janez, Rojstna imena, hišna imena, vzdevki, psevdonimi v Sloveniji, Jezikoslovni zapiski 8 (2002), št. 2, 47-69.

Keber, Janez, Imena v rimah, Družinska pratika, 1995, 48-51.

Keber, Janez, Urha klicati, Zakaj tako, $7 D$ (Maribor), 1. oktober 2003, letn. 52, št. $39,50$.

Keber, Janez, Iti kot Elija, Zakaj tako, 7D (Maribor), 17. nov. 2004, letn. 53, št. 46, 50.

Keber, Janez, Leksika in frazeologija iz osebnih imen, Ivić, Pavle (ur.), Zbornik šeste jugoslovenske onomastičke konferencije (Donji Milanovac, 9-12. oktobar 1985), (Naučni skupovi, Odeljenje jezika i književnosti, knj. 37, knj. 7), Beograd, Srpska kademija nauka i umetnosti, 1987, [437]-443.

Keber, Janez, Izimenska leksika in frazeologija v Slovarju slovenskega knjižnega jezika, Rječnik i društvo : zbornik radova sa znanstvenog skupa o leksikografiji i leksikologiji održanog 11-13. X. 1989. u Zagrebu, (Znanstveni skupovi razreda za filološke znanosti, knjiga 2), Zagreb, Hrvatska akademija znanosti i umjetnosti, 1993, 183-188.

Keber, Janez, Ženska imena v Sloveniji, Derganc, Aleksandra (ur.), Zbornik predavanj, Ljubljana, Filozofska fakulteta, Oddelek za slovanske jezike in knjiŽevnosti, 1997, 33-43.

Keber, Janez, Einige semantische Aspekte und Motive des Übergangs von Personennamen zum Appellativum im Slowenischen, Zusammenfassungen, Trier, Universität Trier, 1993, 72-73.

Keber, Janez, Ob slovenskem imenoslovju, v: Merkù, Pavle, Svetniki v slovenskem imenoslovju, Trst, Mladika, 1993, 155-157.

Keber, Janez, Leksikon imen, Izvor imen na Slovenskem, tretja, dopolnjena izdaja, Celje 2001.

Keber, Janez, Frazeološki slovar slovenskega jezika, Poskusni zvezek, Ljubljana 2003.

Kopaliński, Władysław, Słownik mitów i tradycji kultury, Warszawa 1987.

Lađević, Milica, Tvorbeni modeli imena blizanaca u Vojvodini, Novi Sad 1988. 
Matešić, Josip, Frazeološki rječnik hrvatskoga ili srpskoga jezika, Zagreb 1982.

Merkù, Pavle, Odprto pismo Janezu Kebru, Primorska srečanja 1989, št. 95-96, str. 299-301.

Merkù, Pavle, Svetniki v slovenskem imenoslovju, Mladika, Trst 1993.

Mrazović, Pavica, Primorac, Ružica, Nemačko-srpskohrvatski frazeološki rečnik, Beograd 1981.

Žukov, V. P., Slovar' russkih poslovic i pogovorok, Moskva 1966, 459.

\section{Pavle Is Pavel, but He Was Not Savel, And Also Not Peter in Pavel nor Peter ali Pavel nor pavliha \\ Summary}

This article dedicated to Pavle Merkù discusses the vocabulary and phraseology connected with the name Pavel 'Paul'. Following an introduction, it focuses on the names Pavle and Pavliha, and the name of the comic character Pavliha, as well as the terms pavliha, pavlišec, pavlišek, and pavluha (all 'clown'), in addition to the phrasemes iz Savla postati Pavel 'for Saul to become Paul', Peter in Pavel 'Peter and Paul', Peter ali Pavel 'Peter or Paul', biti pavliha 'to be a clown', imeti koga za pavliha 'to make fun of someone', and igrati pavliho 'to play the clown'. In the article's title, the author provides a more rhetorical answer to the question of whether the saying Nomen est omen 'true to its name' also applies to Pavle Merkù with regard to this name, vocabulary, and phraseology.

\section{Janez Keber}

Inštitut za slovenski jezik Frana Ramovša ZRC SAZU

Novi trg 2, 1000 Ljubljana

keber@zrc-sazu.si 